\title{
The effects of pollution and the need for long-term monitoring
}

\author{
J. B. Pearce \\ Sandy Hook Laboratory, Northeast Fisheries Center (NEFC), National Marine Fisheries \\ Service; Highlands, New Jersey 07732, USA
}

\begin{abstract}
The general deterioration of coastal water quality and physical despoilation of habitats along the eastern United States coastline has had a major impact on estuarine and coastal fisheries. To understand the full extent of these effects, and to provide data on the rate at which they are spreading geographically, a new monitoring program called Ocean Pulse has been implemented. Ambient levels of contaminants in waters and sediments of the coastal zone are documented, and biological effects are monitored in habitats over the continental shelf as far seaward as high levels of contaminants can be measured. Samples and experimental measurements are taken at contaminated and uncontaminated sites between the Canadian boundary and Cape Hatteras. The primary aim of the Ocean Pulse program is to use changes in physiological/biochemical responses as indicators of biological change due to contaminant loading. Physiological, behavioral, ecological and other responses are measured so as to relate, ultimately, change in community structure, population responses and pathology to variation in the quality of habitat.
\end{abstract}

\section{INTRODUCTION}

\section{Historical perspective}

The current environmental status of the major east coast estuaries of the United States was reviewed in papers (Larsen \& Doggett, 1979; Lippson \& Lippson, 1979; Maurer, 1979; Pearce, 1979; Reid, 1979) presented at the 1979 Statutory Meeting of the International Council for the Exploration of the Sea (ICES). With certain exceptions the waters off Maine, New Hampshire, and northern Massachusetts were considered to be of high quality, with little evidence of deterioration due to specific pollutants. However, the waters and sediments in embayments and sounds, such as Long Island Sound, Raritan Bay, Delaware Bay and Chesapeake Bay, which are near major urban areas and industrial zones, were often found to be highly polluted by a wide range of industrial and domestic contaminants. High heavy metal levels were frequently found, and organic substances such as petroleum hydrocarbons and PCBs occurred at much higher levels in the physical environment and in biota than was the case in estuarine waters known to be relatively unpolluted.

The estuarine portions of major east coast rivers, as well as many bays, have been polluted for decades. Goode (1887) reported Newark Bay as being so contaminated by petroleum products that oysters and shad could not be sold at the time of the Civil War because they were tainted with coal oil. In 1912, records of the New York Zoological Society indicated that the New York Aquarium, located at the Battery, Manhattan, had to be closed because the water quality of the estuary supply system was so poor that fish 
could not survive in it. By World War I, Nelson (1916) noted that the industrial wastes being discharged into Raritan Bay threatened the very existence of the commercial oyster resources in the bay.

In spite of the existence of these conditions, for over a century little scientific study was conducted in heavily polluted waters until the early 1960 s when students at Rutgers University investigated phyto- and zooplankton and benthos (Dean \& Haskin, 1964). Few data, however, were collected on the degree of pollution until the mid to late 1970s, often because sufficiently accurate instruments were not generally available. Moreover, little thought was given to the possible significance of contaminant residues in shellfish and finfish until mercury was found in tuna in the late 1960s. Therefore there are few data to demonstrate changes in the quantity of contaminants in the waters and sediments of estuaries and coastal zones or the rate at which they have affected the well-being of living resources at the population and community levels.

What we do know, however, is that populations and communities from polluted estuaries such as Raritan Bay are reduced in number and are less diverse than those in similar but relatively unpolluted habitats. This seems to be the case in most other polluted estuarine systems along the east coast of the United States and, to some extent, in the highly polluted areas of San Francisco Bay, Puget Sound and Los Angeles-Long Beach Harbor areas.

Recent studies suggest that pollution loading and concomitant changes in populations can be reversed with proper treatment of wastes (Reish et al., 1980). Unfortunately, it is difficult to prove the effects of individual contaminants much less those of gross pollutants such as domestic and industrial sewage. Without demonstrating cause and effect, it is usually impossible to obtain funds for the massive programs of pollutant control required to alleviate the adverse conditions and stresses. It is therefore important to conduct research and monitoring efforts that will allow marine scientists and environmental managers to establish environmental baselines for demonstrating acute and chronic change as well as signaling the point at which pollutants affect the life cycles of marine organisms important in estuarine and shelf productivity.

From recent work done by personnel of the Northeast Fisheries Center (NEFC) it is apparent that the contaminant loading of Raritan Bay and Long Island Sound is extensive (Greig \& McGrath, 1977; Greig et al., 1977). Moreover, it is known that the effects of pollution have been extended offshore due to ocean dumping and terrigenous export of contaminants. High levels of heavy metals and petroleum hydrocarbons have been found repeatedly in sediments of the New York Bight and significant changes in benthic communities have been noted (Pearce, 1972; Steimle et al., in press; Swanson et al., 1979). Perhaps most important, increases in heavy metals have been found in the body tissues of surf clams (Spisula solidissima) collected at sampling stations at the northern, more polluted, end of a transect from Virginia to Long Island Sound, New York (Fig. 1) (Wenzloff et al., 1979). Such recent measurements form preliminary baselines for research and monitoring programs.

\section{The plan for environmental monitoring and research}

To determine the effects of long-term environmental changes on marine and estuarine organisms, it is necessary to conduct assessment and monitoring programs over 

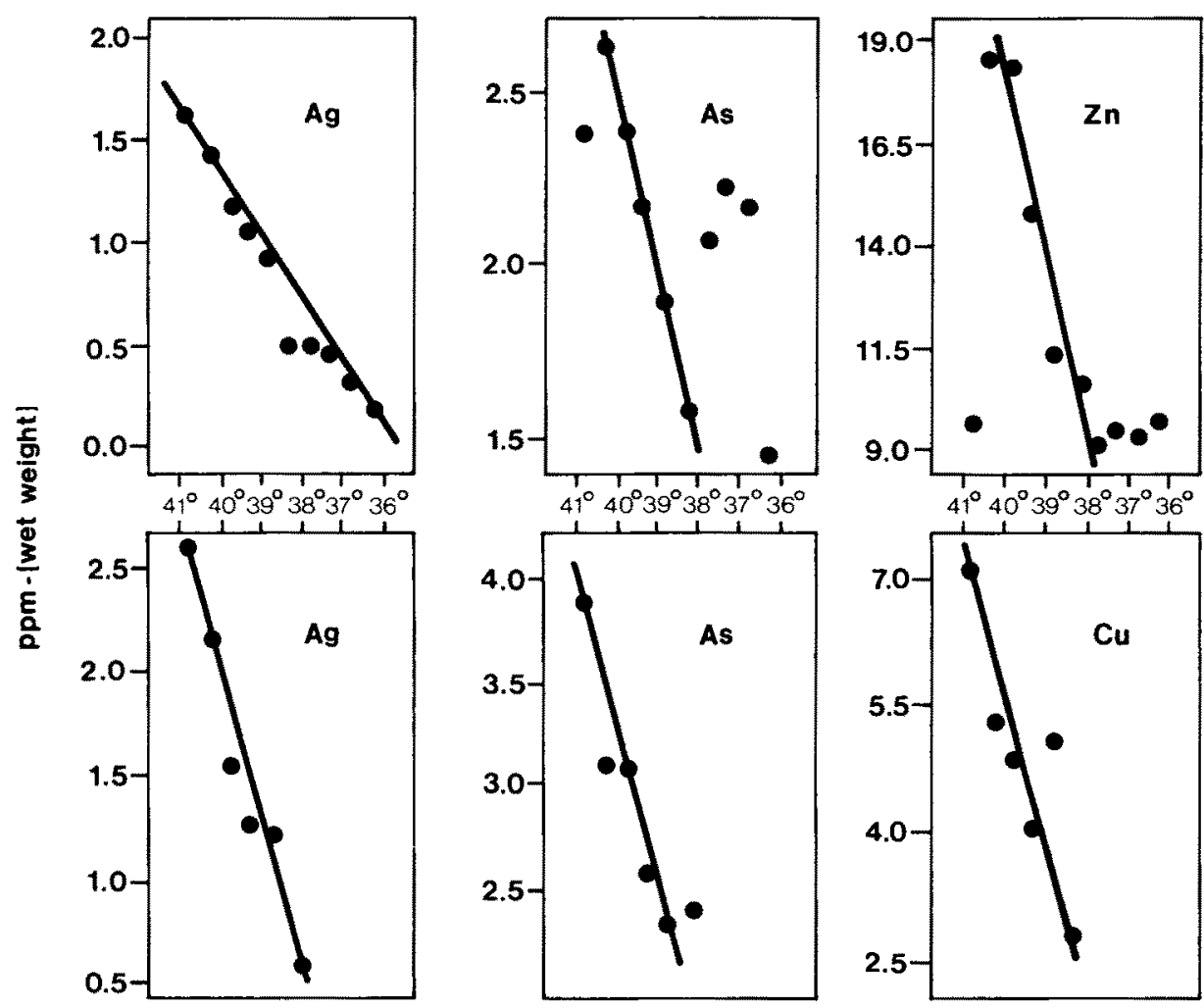

$\frac{5}{5}$
$\frac{5}{5}$

Fig. 1. Concentrations of heavy metals ( $\mathrm{Ag}, \mathrm{As}, \mathrm{Cu}, \mathrm{Zn}$ ) in two species of clams, the surf clam (Spisula solidissima) and ocean quahog (Arctica islandica), distributed at latitudes between Cape Hatteras and Long Island. With increasing latitude, and closer proximity to major urban areas and industrial dumping, the body burdens of these metals increased significantly

decades. International organizations and national agencies have begun planning such acitivities. For instance, ICES held planning workshops (ICES, 1976) which resulted in ICES Cooperative Research Report No. 75 (ICES, 1978). In February 1979, a subsequent international workshop under the aegis of ICES at Duke University Marine Laboratory brought together scientists from 14 nations. Scientists were organized into panels representing behavior, bioassay techniques, biochemistry, ecology, genetics, pathobiology and physiology. The panel reports and individual papers included recommendations for the use of specific disciplines as part of a biological effects monitoring program. They are published as part of the overall proceedings of the second ICES workshop on biological effects monitoring (McIntyre \& Pearce, 1980).

More recently, a United States Interagency Committee on Ocean Pollution, Research and Development, and Monitoring prepared a draft "Federal plan for ocean pollution research, development, and monitoring, 1979-83". Other units such as the National Oceanic and Atmospheric Administration (NOAA), Marine Ecosystems Analysis (MESA) 
Program have also proposed monitoring plans for particular areas (Swanson et al., 1979).

In 1977, the National Marine Fisheries Service (NMFS), NEFC, began to design and implement an environmental assessment and monitoring program called Ocean Pulse. Described by Pearce (1977) and Calabrese et al. (1978) during the ICES Statutory Meetings in 1977 and 1978, this new program is designed to assess and monitor the relative health of the ocean's living resources on the continental shelf of the Northwest Atlantic from Cape Hatteras to the Canadian border. Program participants collect and analyze data on the effects of pollutants and natural fluctuations on the survival, growth, metabolism and productivity of important marine species.

The continental shelf waters to be studied are among the most productive in the world. Primary production averages $150 \mathrm{grams}$ of carbon $/ \mathrm{m}^{2} / \mathrm{yr}$, and supports an annual catch of approximately one million metric tons of fish. Monitoring the condition of these fisheries and their environment is important for many reasons: (1) pollution and other environmental alterations of marine waters can have significant effects on living marine resources and result in irreversible losses of habitat; (2) pollutants tend to become concentrated in marine organisms, which thus serve as useful indicators of the distribution of the pollutants; (3) in addition to indicating the existence of pollution, marine organisms are themselves an important transport medium for pollutants; and (4) many of the species to be monitored are valuable food resources, and their contamination by pollutants may be a public health hazard.

Fish and shellfish resources off the northeast coast of the United States are subjected to increasingly heavy contamination by dumped and discharged industrial and domestic wastes (Mueller et al., 1976) as well as by oil from spills and leaks. These pollutants have destroyed or greatly reduced the value of some fish populations, and have caused more subtle but cumulative damage to others. Results from studies of environmental impact, most of which are being conducted in limited areas and for relatively short time spans, suggest that pollution-related changes in marine populations gradually take place over longer periods of time and in larger areas than are now being studied. To separate the complexities of the effects of pollution on fish populations and distinguish them from the effects of natural environmental changes, it is necessary to obtain data from broad geographic areas over extended periods of time, studying both polluted and relatively clean control areas. It is frequently pointed out that while many contaminants can be shown to have specific effects on marine organisms in the laboratory, it is far more difficult to determine the actual effects of comparable levels of contaminants or pollution in the field. Moreover, there is always the possibility that contaminants act in a synergistic fashion.

\section{RESULTS TO DATE}

To understand the integrated and specific effects of various levels of contaminants in the field requires that experiments be performed in situ, using waters and sediments from a particular site or stratum to challenge indicator and indigenous fauna. Moreover, synoptic measurement of changes over thousands of kilometers of the shelf requires the application of remote sensing techniques which either directly measure a pollutant or a substance representative of pollution.

During the past 18 months considerable progress has been made by the NEFC using several new techniques and methodologies, including remote sensing. 


\section{Physiology and biochemistry}

During recent Ocean Pulse cruises selected species of animals have been subjected to in situ experiments to determine their physiological and biochemical responses to waters and sediments of differing environmental quality.

Over 700 blood and gill-tissue samples have been taken for blood studies and oxygen-consumption measurements, respectively. These two parameters are among the physiological measurements suggested by the ICES Biological Effects Workshop (Bayne et al., 1980). More than 600 tissue samples were similarly collected for biochemical examination: flounder kidney, bivalve adductor muscle, and crustacean heart, primarily. These were examined for enzymes involved in carbohydrate and nitrogen metabolism; experimentation with the tissues of metal-stressed marine animals has led to the selection of five enzymes for monitoring possible stress effects at locations affected by contamination. Enzymes can be used as subcellular indicators of the rates of energy mobilization, of reductive biosynthesis, and of amino acid pool activity. Although this method of measuring biological effects was not singled out for discussion in the ICES workshop report (Lee et al., 1980), it has proven to be a rapid, inexpensive, sensitive indicator of sublethal stress in all animals examined thus far (reviewed in Calabrese et al., 1977 and in press).

Ocean Pulse cruises to date, as well as collaborative work with NEFC resourceassessment cruises, have provided the base for a data bank for seasonal baseline information on the metabolism of four target species: Cancer irroratus (rock crab), Placopecten magellanicus (sea scallop), Pseudopleuronectes americanus (winter flounder), and Scophthalmus aquosus (windowpane flounder). Physiological parameters show relatively consistent values from station to station for each species, with natural variations expected with season and temperature. In scallop adductor muscle, there seems to be a general trend of lower malate dehydrogenase activity with increasing bottom temperature, and of lower malate and lactate dehydrogenase activities with increasing depth. Baseline information, therefore, must include not only the physiological variables of sex, size, and reproductive stage, but also the hydrographic variables of temperature, depth, and dissolved oxygen.

Investigators with the program are also researching the use of RNA-DNA ratios as a monitoring tool. Working with winter flounder and haddock (Melanogrammus aeglefinus) larvae, they have found that while temperatures near or below the optimal levels markedly affect growth rates, the RNA-DNA ratio is not similarly affected. Field specimens have been found to have high ratios (4.1 to 5.6). Previous laboratory studies found a range of 3.5 to 6.0 for well-fed larvae; larvae starved for two days had a range of 3.5 to 1.8 (Buckley \& Laurence, 1980). These studies are continuing to determine how natural variables and man-induced stresses affect RNA-DNA ratios and how these can be used to monitor the health of coastal and shelf waters.

\section{Microbial ecological studies}

During 1979 and 1980, the Pathobiology Division, NEFC, studied the fouling organisms on gills of the rock crab, Cancer irroratus, collected in Raritan Bay, an inshore Ocean Pulse site studied in conjunction with the New Jersey Sea Grant Program/U. S. 
Environmental Protection Agency. Small predetermined samples of 12 animals were collected to test a hypothesis that adult crabs present in the Bay during summer months are "stragglers" that fail to migrate seaward during the spring months. Previous studies showed that adult rock crabs generally were absent or caught in small numbers in the summer. Crabs that were collected during the summer usually had shell erosion, blackened articulations and bryozoan growth on the carapace. Microscopically, they had discolored or blackened gills, heavy gill fouling by bacteria and diatoms, and dense populations of attached and free ciliate protozoans. Of the crabs examined during the summer of 1979 , only one had clean gills. The gills of the other animals were either discolored or black; six had dense bacterial fouling and one had heavy diatom infestation. On one section of a gill, there were over 300 ciliated protozoans. Gross and microscopic observations on the samples supported the hypothesis that the residual summer population is ideal for continued Ocean Pulse studies on the effects of environmental contamination and microbial fouling. Similar observations are being made of macrocrustaceans found in the New York Bight apex dumping areas and at relatively uncontaminated control stations.

In addition to studies of disease and microbial parasites, NEFC personnel at the Milford Laboratory are investigating various microbial indicators of environmental deterioration. During recent cruises (March-April 1980) bacterial subcultures, both by direct culture and pre-enrichment procedures, were made from 33 bottom sediments and 16 water samples and from 15 scallops. Some 434 isolates were obtained from our selective and differential media for identification after quantitative enumeration of the bacteria.

Clostridium perfringens counts in sediments varied from less than 50 (lowest detectable limit by the procedure used) to 19,250 per gram of sediment (sewage disposal site). As observed previously, bacterial counts during the winter sampling period were less than those observed during the warm summer months.

Of 74 isolates tested for perfringens type, $69 \%$ were $C$. perfringens. The bacteriological procedures used were specific for $C$. perfringens, but other clostridial types can also be detected with this technique. Additional procedural development and identification of the isolates are warranted before final adaptation of this methodology for monitoring.

From 360 isolates obtained on vibrio media, 125 were Gram negative rods $(90 \%$ of the microorganisms in the marine environs are such), of which 46 were biochemically identified to species by the API system. The remainder did not fit any identifiable group in the scheme employed. This is in line with earlier results. However, those bacteria identified are of interest to the fisheries and are grouped in Table 1.

Of 15 cultures isolated from scallops (anaerobic pre-enrichments), none of the supernatants were toxic to mice on the first screening. However, on treatment with trypsin, 7 of the 15 supernatants $(46.6 \%)$ were toxic to mice. Further characterizations are continuing.

As previously noted, C. perfringens, an indicator of persistent fecal pollution, is most numerous in sediments from the sewage disposal areas of the New York Bight but also has been found in sediments from the northern edge of Georges Bank, although sediments at most offshore stations had no detectable numbers of this organism. In the water column, surface waters had a greater concentration of $C$. perfringens than the 
Table 1. Bacteria identified

\begin{tabular}{|lr|}
\hline Species & $\%$ \\
\hline Pseudomonas fluorescens & $12 / 125-9.6$ \\
Aeromonas hydrophila & $9 / 125-7.2$ \\
Pseudomonas putrefaciens & $6 / 125-4.8$ \\
Vibrio alginolyticus & $6 / 125-4.8$ \\
Vibrio species (lactose \& halophilic) & $6 / 125-4.8$ \\
Vibrio cholerae (NA) & $4 / 125-3.2$ \\
Vibrio parahaemolyticus & $2 / 125-1.6$ \\
Chromabacterium & $1 / 125-0.8$ \\
\hline
\end{tabular}

bottom waters, with the greatest numbers in surface microlayers. Sulfate-reducing anaerobes were found only in the sediments obtained from the highly polluted New York Bight.

\section{Pathobiological monitoring of plankton}

Other investigators have begun the study of the possible impact of deep water disposal of industrial wastes on planktonic and pelagic organisms at the 106-mile site. This area is located beyond the shelf-slope break off Atlantic City, New Jersey. Initially the external gills of euphausids are being examined to determine if dumping activities are resulting in distinctive disease syndromes involving gill tissues. Very preliminary data indicate darkened gills in specimens collected from the offshore sites in the dumping area, relative to specimens taken closer inshore over the shelf. Further monitoring and research is required to determine if this is an interspecific difference or the result of anthropogenic activities.

\section{Parasite investigations}

Winter flounder are an important commercial resource and, because of their wide distribution and sedentary nature, are a useful general model to study the effects of pollution on parasitism in marine fish. Seasonal and geographic fluctuations in parasite occurrence, diversity, and pathogenicity are being observed as part of Ocean Pulse and, ultimately, may be correlated to specific environmental factors including minimal and gross levels of pollution.

Samples have been collected intermittently at several Ocean Pulse sampling strata for approximately 18 months; marked fluctuations in parasitism have been observed. The level of parasitism was very low in the heavily polluted New York Bight, possibly due to a reduction of available intermediate hosts in this area. Cleaner inshore habitats displayed greater numbers of parasites, particularly the acanthocephalan, Echinorhynchus gadi. Offshore on Georges Bank, parasite abundance was reduced despite ostensibly unpolluted conditions. The reasons for this "natural" low level of parasitism are not known. The occurrence of most parasites has been found to be lower during the winter months.

The diversity of the parasite community was lower in known (New York Bight) and potentially (Argo Merchant site) impacted areas than in other habitats. This may be 
related to a similar pattern in the diversity of the free-living biota, but such data are not yet available. Since the diversity of free-living communities is considered to be a useful indicator of changes in environmental quality, such a relationship of pollution to parasitism would have implications both for fish health and the potential use of parasite data for environmental monitoring. Parasite diversity is convenient because it is based on a small and easily defined community, and thus is easily calculated.

\section{Phytoplankton abundance and diversity}

One of the most significant components of the marine system is the phytoplankton, which includes the major autotrophic forms within marine waters responsible for carbon fixation and oxygen production. The dependence and interaction between the phytoplankters and various fauna have been well documented. Due to their brief life span, high repoductive potential, and their responsiveness to existing ecological conditions, phytoplankters represent an excellent community index to various changes within the ecosystem.

A cooperative study of phytoplankton in waters off the northeastern United States was initiated this summer by personnel of Old Dominion University (Norfolk, Virginia) and the NEFC Sandy Hook Laboratory. Phytoplankton is identified from a broad range of Ocean Pulse strata on the continental shelf. During the past 18 months abundance values and distribution patterns have been determined for surface waters and a series of depths at selected stations. The dominant phytoplankters are identified, and the total species composition compared with data available from the last eight years. One of the major advantages of the present study is that it begins the analyses of data from long-term seasonal studies involving collections from several cruises made over one to two decades. Results of these studies will lead to the establishment of a phytoplankton composition base for these waters. Critical strata have been identified which represent locations of collection sites for use in the Ocean Pulse monitoring program for identifying and predicting the population dynamics of phytoplankton in coastal and oceanic waters off the northeast and mid-Atlantic coasts.

In early 1980 there was an indication that the dinoflagellate, Ceratium tripos, thought to contribute to the extensive and persistent anoxia off the New Jersey coast in 1976, was increasing in New England waters in a manner which might indicate another reduced dissolved oxygen event. However, the results of analyses done during our monthly Ocean Pulse cruise indicated that $C$. tripos densities at shelf stations in the New York Bight ranged between 177 and 257 cells/1, well below the levels found in early 1976 when the last major anoxia occurred.

\section{Remote sensing}

A Large Area Marine Productivity-Pollution Experiment (LAMPEX) to test the feasibility of measuring and mapping chlorophyll $a$ and total suspended solids concentrations, and possible associated pollutants, in surface waters of the continental shelf 
from Cape Hatteras to the Canadian border, was conducted jointly by the National Aeronautics and Space Administration (NASA), Langley Research Center, Marine Environments Branch and the NMFS, NEFC, Division of Environmental Assessment during the period of 17-21 April 1979 as part of the Ocean Pulse program; 111 people from 25 federal, state and private research facilities on 19 research vessels and 3 aircraft participated in the experiment. NASA was responsible for the remote sensing systems, data collection, and reduction. The NMFS, with the cooperation of other federal, state and private research facilities, was responsible for the organization, collection and reduction of sea-truth data to calibrate the remote sensors.

During the experiment NASA accomplished remote sensing using two aircraft, a U-2 flown at $19.7 \mathrm{~km}(65,000 \mathrm{ft})$ with an Ocean Color Scanner (OCS) and Mitchell-Vinton* cameras using aerial color and multispectral film and a NASA C-130 at $3.0 \mathrm{~km}(10,000 \mathrm{ft})$ with a multispectral scanner (Modular Multispectral Scanner M2S) and Zeiss * mapping camera using aerial color film. The sea-truth data were collected at locations between Cape Hatteras and the Canadian border. Additionally, Landsat imagery for these same locations and approximate times is being examined by personnel at the University of Delaware.

The U-2 inflight observations suggested successful, cloud-free coverage of a 14-mile wide swath along the coast between 19 and 21 April from Oregon Inlet, North Carolina, to the Canadian border including Long Island Sound, but not Georges Bank. Inflight observations by the C-130 on 17 and 19 April indicated successful coverage where concurrent sea-truth was available from Chesapeake Bay to Cape Cod, except for the coastal zone of New Jersey off Barnegat Inlet and Long Island of Fire Island Inlet where cloud cover prevented data collection. Cloud and light conditions hindered data collection north of Cape Cod and over Georges Bank.

A report presenting the sea-truth data collected in conjunction with the NASA C-130 overflights on 17 and 19 April 1979 was recently prepared (July 1979) for review and distribution to participants and users (Thomas et al., 1979).

We have found that remote sensing has the capability of extending a "lone" ship's observations outward, spatially, and both forward and backward temporally. While it does not have the same degree of precision as sea surface measurements, remote sensing can allow us to determine how representative our ship data are both in time and in space. Only via remote sensing can we respond to certain environmental questions such as those involving phytoplankton with generation times of 1 to 3 days or seaward movements of estuarine fronts and entrained pollutants (Klemas \& Polis, 1977). In April and June 1980 we conducted two studies to determine if remote sensing can be used to estimate the seaward movements of entrained suspended matter and associated contaminants in plumes emanating from Chesapeake and Delaware Bays. Synoptic with data collected from aircraft, Ocean Pulse personnel collected samples for contaminant and bacterial analyses from stations located along the distance covered by plumes of outflowing waters. Resulting data from these and two future cruises will be correlated with remotely sensed imagery to determine the efficacy of remote sensing in measuring the seaward extent of pollution and possible impacts on fisheries ecosystems.

\footnotetext{
* Mention of these trade names does not constitute endorsement
} 


\section{Contaminant levels in biota and their habitat}

While considerable information exists on the distribution and abundance of metals and organic contaminants in estuarine and shelf sediments off the northeast and middle Atlantic states, relatively little information exists on contaminants in water, particularly from the less polluted offshore areas. Recently, Dr. L. V. Sick, University of Delaware, and the NMFS Charleston Laboratory, measured dissolved and particulate trace metal concentrations at water column stations in the Gulf of Maine. These measurements serve as a preliminary Ocean Pulse baseline for unpolluted waters for assessing future trends in trace metal concentrations and to further understand natural variations and fluxes of metals. During the autumn, 1978, typical nearshore maxima were found for dissolved cadmium, copper, lead, manganese, nickel, silver and zinc. Within the water column, subsurface maxima values at approximately $10 \mathrm{~m}$ were found for all trace metals measured, except manganese. Manganese was uniformly distributed throughout the water column at all stations. Copper and zinc to manganese ratios indicated enhanced particulate copper and zinc concentrations approximately $23 \mathrm{~km}$ from shore. Such enhancement, intermediate between coastal and far offshore environments, was possibly associated with physical hydrographic features and the location of a phytoplankton bloom.

Results from this study in the Gulf of Maine were coupled with studies of trace metal partitioning between selected abiotic and biotic components of the Georges Bank ecosystem. Hydrographic spatial distributions of trace metals on Georges Bank were similar to those found in the Gulf of Maine. However, physical oceanographic features were found to have a significant forcing function in trace metal dynamics on Georges Bank. For example, during the winter season most suspended particulate trace metals had a maximum concentration within the water column associated with the shelf-slope break' front. In contrast, during late summer, when the shelf-slope break front was largely dissipated, highest particulate trace metal concentrations were found at midshelf and nearshore stations. This seasonal geographic trend in particulate trace metal concentrations was reflected in tissue concentrations of selected pelagic/planktonic and benthic organisms.

In addition to our concern for the dynamics and impacts of metals in coastal and offshore habitats, the Ocean Pulse program is also monitoring the levels of organic contaminants, such as PCBs and petroleum hydrocarbons, in biota, sediments and waters along the eastern seaboard of the United States. Figure 2 shows the biological effects of certain forms of petroleum hydrocarbons; at levels well below those reported for New York Bight coastal $(252 \mu \mathrm{g} / \mathrm{l})$ and estuarine waters $(2300 \mu \mathrm{g} / \mathrm{l}$; Searl et al., 1977) and estuarine and coastal sediments (6530 ppm; Koons \& Thomas, 1979), marine organisms are shown to be affected by petroleum hydrocarbons in various ways, ranging from behavioral responses such as overt displays elicited in detection, to mortality. A recent series of analyses of finfish collected from the Middle Atlantic Bight, following the sinking of the tanker "Argo Merchant", showed that even fish collected from areas not affected by this sinking contained what appeared to be elevated levels of petroleum hydrocarbons. In February 1980, collections of fish were made along transects off major estuaries and rivers between the Canadian and Mexican borders known to be heavily polluted by oil, as well as at control sites thought not to be heavily polluted. The analyses 


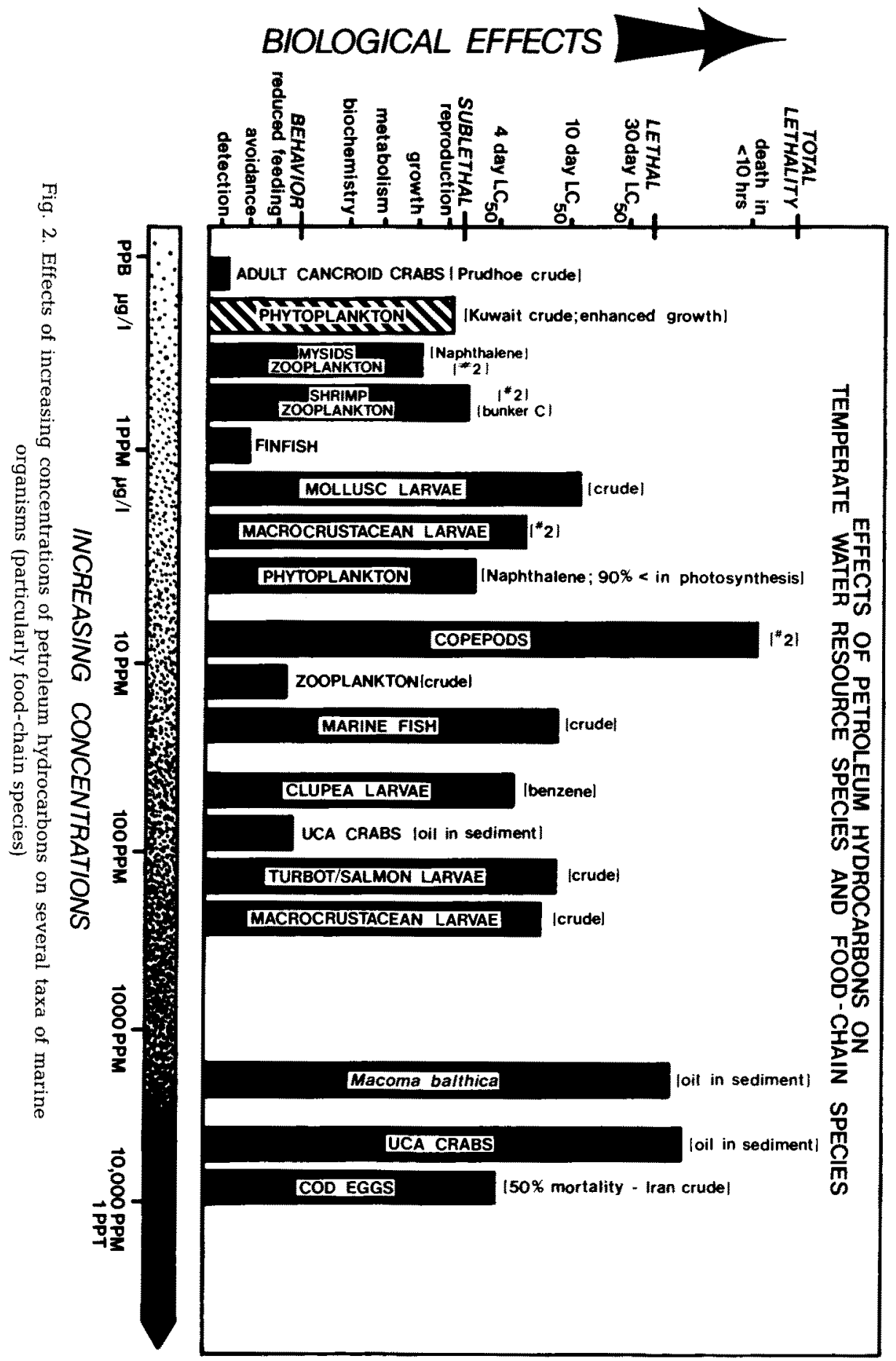


of these samples are just beginning but will form an important part of the Ocean Pulse pollutant baseline.

\section{Benthic populations}

While previous studies have resulted in significant benthic baselines for the Middle Atlantic Bight, New York Bight and Georges Bank, there have been few data available for the Gulf of Maine, especially the productive seamounts such as Pigeon Hill. The Gulf is increasingly being developed and subject to anthropogenic inputs of a variety of wastes. Diving biologists from the University of New Hampshire, working with NOAA/ NMFS scientists have recently completed the establishment of baselines for Pigeon Hill. Following the publication of their first report (Witman et al., 1980) they have begun a series of monitoring dives to begin to document long-term changes in populations and community structures, as well as to collect tissue and sediment samples to detect possible changes in contaminant loading in key biota and their physical environment.

In addition to the benthic baselines developed for Pigeon Hill, personnel from Bigelow Laboratory, Maine, have completed a census of benthic communities at 56 stations in the Portland (Maine) Harbor and Casco Bay. In addition to establishing the baselines for the megabenthic organisms they have collected sediments for analyses for $\mathrm{C}: \mathrm{H}: \mathrm{N}$ ratios.

The aforementioned benthic studies, plus the earlier and ongoing monitoring and research in the Middle Atlantic Bight, form the first continuous set of benthic baseline data for the area between the Canadian border and Cape Hatteras.

\section{CONCLUSIONS}

Of necessity, the foregoing report is brief and does not include all disciplines or activities conducted within the Ocean Pulse program. For instance, many additional efforts are being made in the areas of benthic ecology, phytoplankton productivity, and genetics (chromosomal aberrations) to establish baselines for populations, community structure and chromosome stability to determine how man-induced pollution and natural variations affect living resources. Moreover, far more extensive work is carried out by Ocean Pulse in the general areas of behaviour, pathobiology, and physiology than is reported here.

During the first two years of the program, investigators working in over 30 different tasks or investigations, are establishing the degree of variability in specific biochemical, ecological and physiological responses of key or indicator organisms in several habitats which are contaminated to various degrees.

The areas of research designated as monitoring must be done concurrently with laboratory research designed to determine the sublethal effects of various contaminants on key or indicator species. The recent summary by Sindermann (1979, p. 448) on this matter should be heeded: "Physiological studies of pollutants in the coastal/estuarine environment - heavy metals, petroleum components, and halogenated hydrocarbons have provided much information about effects on the biota. Data from laboratory experiments, combined with field observations and results of field experiments, reduce intuitive conclusions and expand areas of genuine understanding. There is still, however, a large area of uncertainty about multiple pollutant effects on marine organisms, 
and the critical problem of resistance to contaminant toxicity is only now beginning to be elucidated. A satisfying shift of emphasis toward understanding sublethal effects of long-term exposure to contaminants and away from artificial short-term acute exposures has taken place. Additionally, greater attention has been focused on metabolic pathways, induction of resistance mechanisms, and possibilities for monitoring using physiological/biochemical criteria."

Acknowledgements. This paper is a modified version of a contribution given at the Informal Session "Methods for assessing pollution effects" during the 14th European Marine Biology Symposium on the island of Helgoland (September 23 to 29, 1979).

\section{LITERATURE CITED}

Bayne, B. L., Anderson, J., Engel, D., Gilfillan, E., Hoss, D., Lloyd, R. \& Thurberg, F. P., 1980. Physiological techniques for measuring the biological effects of pollution in the sea. - Rapp. P.v. Réun. Cons. int. Explor. Mer 179, 88-99.

Buckley, L. \& Laurence, G., 1980. Larval fish physiology and biochemistry. Bimonthly Rep., Narragansett Laboratory Northeast Monitoring Program, NMFS 1980, 1.

Calabrese, A., Thurberg, F. P. \& Gould, E., 1977. Effects of cadmium, mercury, and silver on marine animals. - Mar. Fish. Rev. 39, 5-11.

Calabrese, A., Thurberg, F. P., Gould E. \& Graikoski, J. T., 1978. Ocean Pulse: some physiological, biochemical, and bacteriological activities. - C. M. - ICES $/ L: 36$.

Calabrese, A., Gould E. \& Thurberg, F. P. Heavy-metal effects in marine animals of the New York Bight: some laboratory observations. In: Ecological stress and the New York Bight: science and management Ed. by. G. F. Mayer, A. Calabrese, F. A. Cross, D. Malins, D. Menzel, J. S. $O^{\prime}$ Connor \& F. J. Vernberg. Estuarine Research Federation, Columbia, South Carolina. (In press.)

Dean, D. \& Haskin, H., 1964. Benthic repopulation of the Raritan River estuary following pollution abatement. - Limol. Oceanogr, 9, 551-563.

Goode, G., 1887. The fisheries and fishing industries of the U.S. Section II. U. S. Government Printing Office, Washington, D. C., 384 pp.

Greig, R. A. \& McGrath, R. A.، 1977. Trace metals in sediments of Raritan Bay.-Mar. Pollut. Bull. 8, $188-192$.

Greig, R. A., Reid, R. N. \& Wenzloff, D. R., 1977. Trace metal concentrations in sediments from Long Island Sound, - Mar. Pollut. Bull. 8, 183-188.

International Council for the Exploration of the Sea, 1976. ICES Working Group on Pollution Baseline and Monitoring Studies in the OSLO Commission and ICNAF areas. - C. M. - ICES/E: 44.

International Council for the Exploration of the Sea, 1978. On the feasibility of effects monitoring.Coop. Res. Rep. ICES 75, 1-42.

Klemas, V. \& Polis, D., 1977. Remote sensing of estuarine fronts and their effects on pollutants. Photogr. Engrg. Remote Sensing 43 (5), 599-612.

Koons, B. \& Thomas, J., 1979, $C_{15}$ hydrocarbons in the sediments of the New York Bight. Proceedings 1979 Oil Spill Conference (Prevention, Behaviour, Control, Cleanup), 19-22 Mar. 79, Los Angeles, California. Am. Petrol. Inst, Washington, D. C., 625-628.

Larsen, P. S. \& Doggett, L. F., 1979. An overview of nearshore environmental research in the Gulf of Maine. - C. M. - ICES/E: 41.

Lee, R., Davies, J., Freeman, H. C., Ivanovici, A., Moore, M. N., Stegeman, J. \& Uthe, J. F., 1980. Biochemical techniques for monitoring biological effects of pollution in the sea. - Rapp. P.-v. Réun. Cons. int. Explor. Mer 179, 48-55.

Lippson, R. L. \& Lippson, A. J., 1979. The condition of Chesapeake Bay - an assessment of its present state and its future. - C. M. - ICES/E: 42.

Maurer, D., 1979. A brief review of the status of selected pollutants (pesticides, hydrocarbons, trace metals) in relation to benthic invertebrates in Delaware Bay, - C. M. - ICES/E: 43. 
McIntyre, A. D. \& Pearce, J. B. (eds) 1980. Biological effects of marine pollution and the problems of monitoring. - Rapp. P.-v, Réun. Cons. int. Explor. Mer 179, 1-346.

Mueller, J., Jeris, J., Anderson, A. \& Hughes, C., 1976. Contaminant inputs to the New York Bight. NOAA Tech. Mem. ERL MESA-6, 1-347.

Nelson, J., 1916. Annual report of the Department of Biology, Rutger University. New Brunswick, N. Y.

Pearce, J. B., 1972. The effects of solid waste disposal on benthic communities in the New York Bight. In: Marine pollution and sea life. Ed. by M. Ruivo. Fishing News Books, London, 624 pp.

Pearce, J. B., 1977. A report on a new environmental assessment and monitoring program, Ocean Pulse. - C. M. - ICES/E: 65.

Pearce, J. B., 1979. Raritan Bay - a highly polluted estuarine system. - C. M. - ICES/E: 45.

Reid, R. N., 1979. Concentrations and effects of Long Island Sound contaminants. - C. M. - ICES/E: 47.

Reish, D., Soule, D. \& Soule, J., 1980. The benthic biological conditions of Los Angeles-Long Beach Harbors: Results of 28 years of investigations and monitoring. - Helgoländer Meeresunters. 34 , $115-249$.

Searl, T. D., Huffman, H. L. Jr. \& Thomas, J. P., 1977. Extractable organics and nonvolatile hydrocarbons in New York Harbor waters. Proceedings of the conference on the prevention, behavior, control and clean-up of oil pollution, 5, 583-588.

Sindermann, $C_{2}, 1979$. Beyond the $\mathrm{LC}_{50}$ an opinion about research activities and needs concerning physiological effects of pollutants in the environment. In: Marine pollution. Ed. by W. B. Vernberg, A. Calabrese, F. P. Thurberg, F. J. Vernberg. Acad. Press, New York, 437-450.

Steimle, $F_{i}$ Caracciolo, J. \& Pearce, J. B. Impacts of dumping on New York Bight benthos. In: Ecological stress and the New York Bight: science and management. Ed. by G. F. Mayer, A. Calabrese, F. A. Cross, D. Malins, D. Menzel, J. S. O'Connor \& F. J. Vernberg. Estuarine Research Federation, Columbia, South Carolina, (In press.)

Swanson, L., Stanford, H. \& Goodrich, D., 1979. A monitoring plan for the New York Bight. - C. M. ICES/E: 48 .

Thomas, J. P., Robertson, C. N. \& Evans, C. A., 1979. Large area marine productivity experiment, LAMPEX I, Sea-Truth Data Report, April 17-19, 1979. Rep. Sandy Hook Lab., Highlands, NJ. SHL-79-28.

Wenzloff, D. R., Greig, R. A., Merrill, A. S. \& Ropes, J. W., 1979. A survey of heavy metals in the surf clam, Spisula solidissima, and the ocean quahog, Arctica islandica, of the mid-Atlantic coast of the United States. - Fish. Bull. U. S. 77 (1), 280-285.

Witman, J., Hulbert, A., Pecci, K., McCarthy, K. \& Cooper, R., 1980. Community structure of the macrobenthos of Pigeon Hill in the Gulf of Maine: a baseline report from the Ocean Pulse Monitoring Program. Zoology Department, University of New Hampshire, Durham, New Hampshire, 82 pp. 